\title{
FAKTOR RISIKO IBU MENYUSUI DENGAN PRODUKSI ASI DI PUSKESMAS 23 ILIR KOTA PALEMBANG
}

\section{RISK FACTORS OF BREASTFEEDING MOTHERS WITH BREAST MILK PRODUCTION AT PUBLIC HEALTH CENTER 23 ILIR IN PALEMBANG CITY}

\author{
Romlah, ${ }^{1}$ Anjelina Puspita Sari ${ }^{1}$ \\ ${ }^{1}$ Fakultas Ilmu Kesehatan, Universitas Katolik Musi Charitas Palembang, Sumatera Selatan, Indonesia \\ (email penulis korespondensi: angelinaps88@gmail.com)
}

Info Artikel: Diterima: 25 April $2019 \quad$ Revisi: 7 Mei $2019 \quad$ Diterima: 30 Mei 2019

\begin{abstract}
ABSTRAK
Latar Belakang: Cakupan ASI ekslusif diseluruh dunia (2007-2014) hanya mencapai 36\%. Indonesia tahun 2015 hanya mencapai 54,3\%, dan Palembang tahun 2015 baru mencapai 72,91\% sedangkan, di Puskesmas 23 ilir tahun 2017 hanya sebesar 42,4\%. Cakupan ASI ekslusif ini masih dibawah target pencapaian $80 \%$ baik di Dunia maupun di Indonesia. Penelitian ini bertujuan untuk mengetahui hubungan umur dan paritas ibu menyusui dengan produksi ASI.

Metode: Jenis penelitian merupakan analitik observasional dengan menggunakan desain cross sectional. Populasi pada penelitian ini semua ibu- ibu menyusui ASI ekslusif dan PASI di wilayah kerja Puskesmas 23 Ilir Palembang. Jumlah sampel dalam penelitian ini 82 responden. Teknik pengambilan sampel dengan Purposive Sampling. Teknik analisa data menggunakan uji Chi-Square.

Hasil: Hasil uji statistik Chi-Square hubungan umur ibu menyusui dengan produksi ASI ( $p v=$ $0,0005)$ dan terdapat hubungan paritas ibu menyusui dengan produksi ASI $(p v=0,001)$.

Kesimpulan: Ada hubungan yang cukup kuat antara paritas dengan produksi ASI. Berdasarkan hasil penelitian ini disarankan untuk Puskesmas 23 ilir kota Palembang untuk tetap menggalakkan pemberian ASI eksklusif terutama bagi ibu- ibu berusia muda dan untuk ibu- ibu yang pertama kali menyusui anaknya
\end{abstract}

Kata Kunci : Umur, Paritas, Produksi ASI.

\section{ABSTRACT:}

Background: The global coverage of exclusive breastfeeding in the period of 2007-2014 only reached $36 \%$. In Indonesia and particularly Palembang, the figure in 2015 only reached $54.3 \%$ and $72.91 \%$, respectively whereas, in the 2017, Puclic Health Center 23 Ilir reached only 42.4\%. It is still below the target both in the World and in Indonesia, that is $80 \%$. This study aimed to determine the age and parity of breastfeeding mothers with breast milk production.

Methods: This study was an observastional analytic with a cross sectional design. The population was all mothers who breastfed exclusively and those who gave complementary feeding in the working area of Public Health Center 23 Ilir of Palembang. The number of samples was 82 respondents taken using purposive sampling. Data analysis technique was Chi-Square.

Results: The results showed a significant relationship between the maternal age and breast milk production ( $p v=0.0005)$ and the parity and breast milk production were significantly related ( $p v=$ 0.001). Based on the results, it is recommended that 23 Ilir Health Center of Palembang continues to promote exclusive breastfeeding especially for young women and new mothers who first breastfeed their children.

Keywords: Age, Parity, Breast Milk Production 


\section{PENDAHULUAN}

Air Susu Ibu (ASI) terbentuk sejak masa kehamilan dan ASI diproduksi secara alami oleh tubuh, merupakan makanan terbaik bagi bayi. Air Susu Ibu mengandung nutrisi yang lengkap dan penting untuk tumbuh kembang bayi. Air Susu Ibu memberikan kekebalan tubuh dan manfaat psikologis bagi kesehatan bayi. Air Susu Ibu hanya dapat diproduksi oleh payudara ibu pada saat masa menyusui dan harus diberikan pada bayi baru lahir sampai bayi berusia 6 bulan, yang disebut ASI eksklusif kemudian dapat dilanjutkan sampai bayi berusia 2 tahun. Susu buatan manusia dihasilkan dari sumber Hewani dan Nabati namun tidak ada satupun yang dapat menyamai komponen dan kualitas ASI. ${ }^{1}$

Seorang ibu dalam masa menyusui bisa memproduksi hingga satu liter ASI per hari. Bayi mengkonsumsi antara 200 hingga $250 \mathrm{ml}$ setiap kali menyusui. Payudara ibu masa menyusui bisa memproduksi jumlah ASI sesuai dengan kebutuhan sang bayi. ${ }^{2}$ Air Susu Ibu ekslusif memiliki konstribusi yang besar terhadap tumbuh kembang dan daya tahan tubuh anak. Anak yang diberi ASI ekslusif akan tumbuh dan berkembang secara optimal dan tidak mudah sakit. Global "The Lancet Breastfeeding Series, 2016" telah membuktikan, 1) menyusui ekslusif menurunkan angka kematian karena infeksi sebanyak $88 \%$ pada bayi berusia kurang dari 3 bulan, 2) sebanyak $31,36 \%(82 \%)$ dari 37,94\% anak sakit, karena tidak menerima ASI ekslusif. Air Susu Ibu ekslusif berguna dalam pencegahan Bayi Berat Lahir Rendah (BBLR), stunting, menurunkan resiko obesitas dan penyakit kronis. ${ }^{3}$

Air Susu Ibu eksklusif memiliki banyak manfaat yang bisa didapatkan, baik bagi ibu maupun bagi bayi. Air Susu Ibu eksklusif secara tidak langsung dapat mengurangi Angka Kematian Bayi (AKB) yang disebabkan oleh berbagai penyakit yang sering menimpa bayi seperti diare dan radang pada paru serta mempercepat pemulihan saat sakit. Angka Kematian Bayi di Indonesia masih tinggi, menurut Survei Demografi Kesehatan Indonesia (SDKI) tahun 2012 dalam Kemenkes RI (2012) AKB di Indonesia pada tahun 2012 sebesar 32 per 1.000 Kelahiran Hidup (KH). Dinas Kesehatan Kota Palembang tahun 2015 melaporkan AKB di Provinsi Sumatera Selatan sebesar 29 per $1.000 \mathrm{KH}$ dan di kota
Palembang sebesar 8 kematian bayi dari 29.011 atau 0.28 per $1.000 \mathrm{KH}^{4}$

Data United Nations International Children's Emergency Found (UNICEF) menyatakan hanya $38 \%$ ibu yang memberikan ASI Ekslusif dan cakupan ASI Ekslusif di Indonesia baru mencapai 55\%. Data ini menunjukkan bahwa bayi di Indonesia masih kurang mendapatkan ASI Ekslusif.. Air Susu Ibu ekslusif telah sering dilakukan kampanye sejak beberapa dekade yang lalu agar ibu menyusui mulai dari bayi baru lahir sampai bayi berusia 6 bulan. Menteri kesehatan membuat peraturan dalam Keputusan Menteri Kesehatan RI No.450/Menkes/SK/IV/Tahun 2014 tentang pemberian ASI Ekslusif di Indonesia menyarankan pemberian ASI Ekslusif selama enam bulan dan menargetkan cakupan sebesar $80 \%$ dan dapat dilanjutkan sampai bayi berusia 2 tahun. ${ }^{6}$

Produksi ASI dipengaruhi oleh berbagai faktor, baik dari faktor eksternal maupun faktor internal. Faktor internal merupakan faktor yang ada pada diri ibu sendiri, antara lain faktor umur dan paritas. ${ }^{7}$ Penelitian Mabud menyatakan bahwa pemberian ASI eksklusif tidak ada hubungannya dengan pengetahuan dan pendidikan, namun untuk variabel paritas memperoleh hubungan yang bermakna dengan pemberian ASI eksklusif. ${ }^{8}$ Penelitian Kitano menyatakan bahwa ibu primipara dan berusia 35 tahun atau lebih menunjukkan rendah atau kurang suksesnya pemberian ASI eksklusif baik pada nol bulan maupun 1 (satu) bulan pertama. ${ }^{9}$

World Health Organization (WHO) tahun 2016 menargetkan pencapaian ASI eksklusif sebesar $100 \%$ tetapi kenyataannya pada tahun 2007-2014 cakupan ASI ekslusif diseluruh dunia hanya mencapai $36 \%{ }^{10}$ Indonesia mengharapkan target pencapaian ASI ekslusif sebesar $80 \%$. Survei Demografi Kesehatan Indonesia tahun 2012 melaporkan pencapaian ASI eksklusif baru mencapai $42 \%$, sedangkan Dinas Kesehatan Provinsi pada tahun 2013 menurut Pusat Data Teknologi dan Informasi (Pusdatin) tahun 2015 cakupan pemberian ASI dari $0-6$ bulan hanya $54,3 \%{ }^{4}$

Air Susu Ibu eksklusif di Kota Palembang tahun 2015 baru mencapai 72,91\%, cakupan ASI ekslusif ini masih dibawah target pencapaian pemberian ASI Eksklusif Indonesia yaitu $80 \%{ }^{11}$ Dinas kota Palembang menyatakan target pencapaian ASI eksklusif sangat 
bervariasi, dimana pada tahun 2015 target pencapaian ASI eksklusif di Puskesmas 23 ilir hanya mencapai 50,6\%, dan tahun 2016 mengalami penurunan menjadi sebesar $41,1 \%$. Puskesmas yang belum mencapai $50 \%$ tahun 2017/ menduduki dua posisi terendah yaitu Puskesmas 23 ilir sebesar 42,4\% dan Puskesmas 7 (tujuh) Ulu sebesar 43,9\%.

Studi pendahuluan di Puskesmas 23 ilir kota Palembang menyatakan bahwa hasil wawancara $10 \mathrm{ibu}$ menyusui yang berumur antara 20 - 40 tahun dengan paritas primipara dan multipara. Enam (6) ibu menyusui

\section{METODE PENELITIAN}

Penelitian ini telah dilaksanakan sejak September 2018 - Februari 2019 di wilayah kerja Puskesmas 23 ilr Palembang. Populasi pada penelitian ini semua ibu- ibu menyusui ASI eklusif dan Ibu yang menyusui ASI dicampur susu tambahan (Bayi 0- 1 tahun) berjumlah $103 \mathrm{Ibu}$ menyusui ASI. Teknik pengambilan sampel dengan Purposive Sampling. Teknik analisa data menggunakan uji statistik Chi - Square.

Penelitian ini dilakukan terhadap 82 sampel ibu menyusui yang memenuhi kriteria inklusi yaitu Ibu menyusui ASI eksklusif

\section{HASIL}

Berdasarkan Tabel 1. diketahui bahwa dari 82 responden ibu menyusui mayoritas berpendidikan SMA berjumlah 54 orang $(65,9 \%)$, mayoritas jenis persalinan normal menyatakan produksi ASI ekslusif cukup, dan 4 orang ibu menyusui menyatakan produksi ASI kurang, yang ditandai dengan bayi masih menangis walaupun telah menyusui pada kedua payudara dan ibu merasakan bahwa kedua payudara kurang kencang, sehingga ibu memberikan susu tambahan/formula.

Peneliti tertarik berdasarkan uraian diatas untuk mengadakan penelitian tentang "Hubungan Umur dan Paritas Ibu Menyusui dengan Produksi ASI Eksklusif di Puskesmas 23 Ilir Palembang?"

setelah masa nifas berakhir, Ibu menyusui dan ditambah dengan susu tambahan setelah masa nifas berakhir, Ibu berusia $\leq 35$ dan $>35$ tahun, Ibu primipara dan ibu multipara, Ibu melahirkan dengan riwayat usia kehamilan aterm (37- 42 minggu), Ibu yang tidak mengkonsumsi suplemen pelancar ASI, Ibu tidak menggunakan $\mathrm{KB}$ yang mengandung hormon estrogen. Pengambilan sampel dilakukan setelah calon responden diberikan penjelasan tentang latar belakang, tujuan dan manfaat penelitian serta mendapatkan persetujuan tertulis dari subjek penelitian.

sebanyak 55 orang $(67,1 \%)$, dan mayoritas memberikan ASI esklusif sebanyak 49 orang $(59,8 \%)$.

Tabel 1. Hasil Analisa Univariat $(n=82)$

\begin{tabular}{lcc}
\hline Karakteristik & Frekuensi & Presentase (\%) \\
\hline Pendididkan & & \\
1. SD & 4 & 4,9 \\
2. SLTP & 13 & 15,9 \\
3. SMA & 54 & 65,9 \\
4. PT & 11 & 13,4 \\
\hline Jenis Persalinan & & \\
1. Normal & 55 & 67,1 \\
2. SC & 27 & 32,9 \\
\hline Pola Menyusui & & \\
1. ASI ekslusif & 49 & 59,8 \\
2. PASI & 33 & 40,2 \\
\hline
\end{tabular}


Berdasarkan tabel 2 menunjukan bahwa responden yang berumur $\leq 35$ tahun memiliki produksi ASI kurang berjumlah 23 responden $(28,1 \%)$, yang berumur $\leq 35$ tahun memiliki produksi ASI cukup berjumlah 18 responden $(21,9 \%)$. Responden yang berumur $>35$ tahun memiliki produksi ASI kurang berjumlah 7 responden $(8,5 \%)$, yang berumur $>35$ tahun memiliki produksi ASI cukup berjumlah 34 responden (41,5\%).

Hasil uji Chi-Square didapatkan p-value $=$ 0,0005 lebih kecil dari 0,05 maka dapat disimpulkan bahwa ada hubungan yang bermakna antara umur ibu menyusui dengan produksi ASI.

Tabel 2 Hubungan Umur Ibu Menyusui dengan Produksi ASI

\begin{tabular}{|c|c|c|c|c|c|c|c|}
\hline \multirow{3}{*}{ Umur } & \multicolumn{4}{|c|}{ Produksi ASI } & \multirow{2}{*}{\multicolumn{2}{|c|}{ Jumlah }} & \multirow{3}{*}{ Nilai $p$} \\
\hline & \multicolumn{2}{|c|}{ Kurang } & \multicolumn{2}{|c|}{ Cukup } & & & \\
\hline & $\mathrm{n}$ & $\%$ & $\mathrm{~N}$ & $\%$ & $\mathrm{n}$ & $\%$ & \\
\hline $\begin{array}{l}\leq \\
35 \text { tahun } \\
>35 \\
\text { tahun }\end{array}$ & $\begin{array}{c}23 \\
7\end{array}$ & $\begin{array}{c}28,1 \\
8,5\end{array}$ & $\begin{array}{l}18 \\
34\end{array}$ & $\begin{array}{l}21,9 \\
41,5\end{array}$ & $\begin{array}{l}41 \\
41\end{array}$ & $\begin{array}{l}50 \\
50\end{array}$ & 0,0005 \\
\hline Total & 30 & 36,6 & 52 & 63,4 & 82 & 100 & \\
\hline
\end{tabular}

Berdasarkan tabel 3 menunjukan bahwa responden primipara yang memiliki produksi ASI kurang berjumlah 22 responden $(26,8 \%)$, responden primipara yang memiliki produksi ASI cukup berjumlah 19 responden (23,2\%). Responden multipara yang memiliki produksi ASI kurang berjumlah 8 responden $(9,8 \%)$, responden multipara yang memiliki produksi ASI cukup berjumlah 33 responden (40,2\%).

Hasil uji Chi-Square didapatkan p-value $=$ 0,001 lebih kecil dari 0,05 maka dapat disimpulkan bahwa ada hubungan yang bermakna antara paritas ibu menyusui dengan produksi ASI.

Tabel 3. Hubungan Paritas Ibu Menyusui dengan Produksi ASI

\begin{tabular}{cccccccc}
\hline \multirow{2}{*}{ Paritas } & \multicolumn{4}{c}{ Produksi ASI } & \multicolumn{2}{c}{ Jumlah } & \multirow{2}{*}{ Nilai $\boldsymbol{p}$} \\
\cline { 2 - 6 } & \multicolumn{2}{c}{ Kurang } & \multicolumn{2}{c}{ Cukup } & & \\
\cline { 2 - 6 } & $\mathrm{n}$ & $\%$ & $\mathrm{~N}$ & $\%$ & $\mathrm{n}$ & $\%$ & \\
\hline \multirow{3}{*}{ Primipara } & 22 & 26,8 & 19 & 23,2 & 41 & 50 & \multirow{2}{*}{0,001} \\
Multipara & 8 & 9,8 & 33 & 40,2 & 41 & 50 & \\
\hline Total & 30 & 36,6 & 52 & 63,4 & 82 & 100 & \\
\hline
\end{tabular}

\section{PEMBAHASAN}

Hasil penelitian ini menunjukkan ada hubungan yang bermakna antara umur ibu menyusui terhadap produksi ASI, hal ini terlihat dari hasil uji statistik Kendall's tau didapatkan $p$-value $=0,000$ lebih kecil dari 0,05 . Ibu menyusui berumur $>35$ tahun rata-rata memiliki produksi ASI cukup berjumlah 34 responden $(41,5 \%)$ dibanding Ibu menyusui berumur $\leq 35$ tahun rata-rata memiliki produksi ASI kurang berjumlah 23 responden $(28,1 \%)$ dari 82 responden.

Ibu yang berumur tua memiliki pengalaman yang lebih dari pada ibu yang berumur muda, hal ini membuat ibu yang berumur tua terus memberikan ASI kepada bayinya. Peneliti berasumsi bahwa selain pengalaman, ibu yang berumur tua juga memiliki pola pikir yang lebih matang dan tidak mudah menyerah dan memiliki mindset yang 
kearah positif dalam mengambil keputusan untuk tetap menyusui, hal ini memberikan manfaat yang merangsang hormon prolaktin tetap bekerja dengan baik seperti diketahui hormon prolaktin berfungsi merangsang sel sel alveoli untuk memproduksi ASI. Sherwood menyatakan bahwa ibu yang memberikan ASI eklusif pada bayinya maka makin banyak ASI yang dikeluarkan atau dikosongkan dari payudara, semakin banyak ASI keluar maka akan semakin banyak pula ASI yang diproduksi. ${ }^{13}$

Penelitian ini sejalan dengan peneltian Mursyida dan Wadus mengatakan bahwa responden yang berumur tua lebih banyak yang memberikan ASI ekslusif, dikarenakan mereka sudah mempunyai pengalaman dalam memberikan ASI ekslusif pada bayinya dibandingkan responden yang berumur muda karena kurang mempunyai pengalaman dalam memberikan ASI ekslusif pada bayinya.14

Penelitian Kitano menyatakan bahwa suksesnya pemberian ASI ekslusif lebih besar pada ibu multipara dengan usia $\geq 35$ tahun dibandingkan dengan ibu primipara usia $>35$ tahun. Penelitian ini juga menunjukkan suksesnya pemberian ASI ekslusif lebih besar pada ibu multipara $<35$ tahun dibandingkan ibu primipara $<35$ tahun. ${ }^{9}$

Penelitian diatas bertentangan dengan penelitian Pranajaya dan Rudiyanti, yang menyatakan bahwa tidak terdapat hubungan antara umur ibu dengan produksi ASI dengan jumlah sampel sebanyak 118 . Hasil penelitian menunjukkan responden dengan usia reproduksi sehat $(n=110)$ mempunyai produksi ASI cukup dari pada responden dengan usia reproduksi tidak sehat $(\mathrm{n}=8)$ dengan $p=0,147$. $^{15}$

Penelitian ini juga bertentangan dengan peneltiian Rahmawati dan Prayogi dimana peneliti membagi usia ibu dalam 4 kelompok 21-25 tahun, 26-30 tahun, 31-35 tahun dan 3640 tahun dengan jumlah sampel 25 orang, kecukupan ASI diukur dengan menggunakan gelas ukur, analisis penelitian menggunakan spearman ranktest, hasil penelitian tidak ada hubungan signifikan antara usia ibu dengan produksi ASI. ${ }^{16}$

Dua penelitian diatas bertentangan dengan hasil penelitian ini dikarenakan jumlah sampel yang berbeda, pembagian kelompok umur yang berbeda, metode penelitian berbeda, walaupun hasil penelitian ini berhunbungan tetapi keeratanan hubungan direntang cukup kuat serta cara melakukan penilaian hasil produksi ASI juga berbeda dari penelitian ini.

Hasil penelitian ini menunjukkan ada hubungan yang bermakna antara paritas ibu menyusui terhadap produksi ASI, hal ini terlihat dari hasil uji statistik Kendall's tau didapatkan $p$-value $=0,001$ lebih kecil dari 0,05. Ibu menyusui multipara rata-rata memiliki produksi ASI cukup berjumlah 33 responden $(40,2 \%)$ dibanding Ibu menyusui primipara rata-rata memiliki produksi ASI kurang berjumlah 22 responden $(26,8 \%)$ dari 82 responden.

Peneliti berasumsi bahwa pada ibu multipara selain sudah berpengalaman, mereka juga mempersiapkan kebutuhan fisik dan psikologis yang berhubungan dengan ekonomi secara terencana dengan matang untuk memperlancar produksi ASI. Ibu Primipara yang kurang pengalaman sering merasa cemas dan tegang setelah melahirkan yang berdampak pada kondisi fisik dan pikologis ibu, kondisi psikologis ibu yang seperti ini dapat menyebabkan terganggunya hormon oksitosin, dimana pada ibu menyusui hormon ini berfungsi mengeluarkan/ memancarkan ASI, hal ini selaras dengan penelitian Kamariyah menyatakan bahwa ada hubungan antara kondisi psikologis ibu dengan kelancaran ASI. ${ }^{17}$

Produksi ASI akan menyesuaikan kebutuhan bayi, dan produksi ASI pada ibu multipara lebih banyak dibandingkan dengan ibu primipara. ${ }^{18}$ Penelitian Hacman menyatakan bahwa banyak ibu primipara melaporkan masalah menyusui dini berhubungan dengan sakit selama minggu pertama postpartum sehingga ibu primipara cenderung menghentikan pemberian ASI atau memberi susu tambahan pada bayi mereka tetapi pada ibu multipara lebih menyukai menyusui sampai lebih dari 6 bulan dan ibu multipara $(n=542)$ signifikan lebih rendah untuk menghentikan pemberian ASI dibanding ibu primipara $(\mathrm{n}=557)$, dengan $p=0,003 .{ }^{19}$

Ibu multipara memiliki pengalaman terhadap anak sebelumnya, sehingga lebih giat dan tekun dalam memberikan ASI pada bayi mereka. Sistem kontrol autokrin dimulai ketika produksi ASI mulai stabil, tahap ini, apabila ASI banyak dikeluarkan, payudara akan memproduksi ASI dengan banyak pula. Produksi ASI sangat dipengaruhi oleh seberapa sering dan seberapa baik bayi menghisap, juga seberapa sering payudara dikosongkan. ${ }^{20,21}$

Penelitian diatas sejalan dengan penelitian Pranajaya dan Rudiyanti, yang menyatakan 
bahwa terdapat hubungan yang signifikan antara paritas ibu dengan produksi ASI dengan jumlah sampel sebanyak 118. Responden multirpara $(\mathrm{n}=46)$ mempunyai produksi ASI cukup dari pada responden primipara (8) dengan $p=$ $0,000 .^{15}$

\section{KESIMPULAN DAN SARAN}

Berdasarkan hasil penelitian bahwa produksi ASI berhubungan dengan umur ibu dan paritas ibu. Perlu dilakukan edukasi bagi ibu- ibu menyusui tentang faktor-faktor yang mempengaruhi produksi ASI untuk memotivasi

\section{DAFTAR PUSTAKA}

1. Suradi. Bahan bacaan manajemen laktasi. Jakarta: Perinasia; 2007.

2. Maryunani A. 2015. Inisiasi menyusui dini, ASI ekslusif dan manajemen laktasi. Jakarta: Trans Info Media.

3. Kemenkes RI. Pedoman penyelenggaraan pekan ASI sedunia (PAS). Jakarta: Kemenkes RI; 2017.

4. Dinkes Kota Palembang.2015. Profil Kesehatan Kota Palembang.

5. Baihaki. 2013. Berita teknologi tersedia. Jakarta.

6. Kemenkes RI. Profil Kesehatan Indonesia Tahun 2014. Jakarta: Kemenkes RI; 2015.

7. Kedem MH, Mendel D, Domani KA, Minmouni FB, Shay V, Marom R. et al. The effect of advanced maternal age upon human milk fat content. Breastfeeding Medicine. 2013: 8 (1).

8. Mabud NH, Mandang J, Mamuaya $T$. Hubungan pengetahuan, pendidikan, paritas dengan pemberian ASI ekslusif di Puskesmas Bahu Malalayang Kota Manado. JIDAN. 2014: 2339-173.

9. Kitano N, Nomura K, Kido M, Murakami $\mathrm{K}$, Ohkubo T, Ueno M, et al. Combined Effects of Maternal Age and Parity in Successful Initiation of Ekslusive Breastfeeding. Elsevier. 2016: 121-126.

10. Balitbangkes. Riset Kesehatan Dasar. Jakarta: Kementerian Kesehatan RI; 2013.

11. Kemenkes RI. 2015. Profil Kesehatan Indonesia. Jakarta.
Ibu dengan paritas tinggi lebih banyak yang memberikan ASI ekslusif, dikarenakan mereka sudah mempunyai pengalaman dalam memberikan ASI ekslusif pada bayinya dibandingkan responden dengan paritas rendah. ${ }^{14}$

ibu- ibu menyusui untuk tetap memberikan ASI eksklusif dan dilanjutkan sampai bayi berusia 2 tahun, terutama pada ibu-ibu yang belum berpengalaman seperti ibu-ibu yang berusia muda dan baru pertama kali menyusui anaknya.

12. Dinkes Kota Palembang. Profil kesehatan Kota Palembang. Palembang: Dinkes Kota Palembang; 2018.

13. Sherwood L. Fisiologi Manusia: dari sel ke sistem. Jakarta: EGC; 2009.

14. Mursyida A, Wadus. Hubungan umur ibu dan paritas dengan pemberian ASI ekslusif pada bayi berusia 0-6 bulan di Puskesmas Pembina Palembang tahun 2013.

15. Pranajaya R, Rudiyanti N. Determinan produksi ASI pada ibu menyusui. Jurnal Keperawatan: 2013; Vol IX no 2.

16. Rahmawati A, Prayogi B. Analisis faktor yang mempengaruhi produksi Air Susu Ibu (ASI) pada ibu menyusui yang bekerja. Jurnal Ners dan Kebidanan: 2017; 2 (4).

17. Kamariyah N. Kondisi psikologi mempengaruhi produksi ASI ibu menyusui di BPS ASKI Pakis Sido Kumpul Surabaya. Jurnal Ilmiah Kesehatan: 2014; Vol2, No 7.

18. Ikatan Dokter Anak Indonesia (IDAI). Pedoman pelayanan medis Ikatan Dokter Anak Indonesia. IDAI; 2009.

19. Hackman NM, Schaefer EW, Beiler JS, Rose CM, Paul IM. Breastfeeding outcome comparison by parity. Breastfeeding medcine: 2014; vol 10 number 3 .

20. Manurung N, Bolon CMT, Manurung R. Sistem endokrin. Yogyakarta: Deepublish; 2017.

21. Idris F. Membesarkan anak hebat dengan susu ibu. Kuala Lumpur: Prin AD SDN BHD; 2013. 